\title{
Political decision-making in the Portuguese New State (1933-39): The dictator, the council of ministers and the inner-circle
}

\author{
Filipa Raimundo European University Institute
}

Nuno Estêvão Ferreira University of Lisbon

Rita Almeida de Carvalho Universidade Nova de Lisboa

\begin{abstract}
This article seeks to contribute to the study of political centralisation in Portugal under Salazar, focusing on the council of ministers and its decision-making role and exploring the links between the dictator and his ministers (1933-39). The authors discuss the centralist strategy of the dictator based on a quantitative and qualitative study of António de Oliveira Salazar's diaries: detailed accounts of his routines, audiences, meetings and even telephone calls. Our conclusions indicate Salazar perceived his cabinet more as a crisis management committee, as meetings occurred irregularly and the agenda was considerably focused on internal and external crises and major international political events. The article also provides a more accurate notion of the main features of decision-making during the regime's institutionalisation by exploring Salazar's individual relations with his ministers and inner circle. As Salazarism is often compared to its Iberian counterpart, Francoism, important differences between the two regimes in this domain are noted.
\end{abstract}

\section{Introduction}

The dictators of the 20th century exerted distinctive levels of political centralisation within their regimes: particularly among their ministerial elites. As a result, institutions were banished, diminished or empowered according to rulers' conception of leadership and power sharing. In that sense, the composition and role of those same institutions represent important pieces of a larger puzzle: that of decision-making under dictatorial regimes.

This article seeks to contribute towards the study of political centralisation in Portugal under Salazarism, focusing on the council of ministers and its decision-making role, and exploring the links between the dictator and his ministers. Although the New State under Salazar's rule lasted from 1932 until 1968, this article focuses exclusively on the years of the regime's institutionalisation.

\section{Keywords}

Salazarism

dictatorships

cabinet

political decision-making Portugal 
1. Salazar kept a detailed diary right up until 1968. He kept a note of a significant part of the meetings and telephone calls he received, and the names of people who missed appointments with him. Unfortunately, he did not keep a detailed account of the matters discussed at meetings. It is widely recognized that the first time his diary was used as a primary source was by Franco Nogueira, who published an official six-volume biography of Salazar during the 1970s and 1980s (Nogueira 1977-1985).

2. The former date is that on which the first government was formed after the promulgation of the 1933 constitution; the second that on which the Spanish civil war officially ended. The diaries for the period 16 August-31 December 1933 were not available. In respect of meetings of the council of ministers, this chronological lacuna was overcome by consulting press notes (AOS/CO/PC-8F, part 1 [1932-1940]). Unfortunately, it was not possible to overcome this absence in relation to Salazar's meetings with political leaders and other individuals. In this sense, the analysis of the frequency and topics debated in the council of ministers includes only AprilDecember 1933 and January-May 1939. It is important to bear in mind conclusions do not include the beginning of the Second
The authors discuss the centralist strategy of the dictator based on a quantitative and qualitative study of António de Oliveira Salazar's diaries detailed accounts of his routines, audiences, meetings and even telephone calls. ${ }^{1}$ The quantitative analysis provides solid proof of the (ir)regularity of council of minister meetings and attests to the (ir)relevance Salazar attributed to this particular institution, as previous studies have sustained (Cruz 1988; Pinto 2002). The qualitative analysis, on the other hand, reveals important aspects of the relationship between the dictator and the individual ministers, which led the authors to rethink former general conclusions about the centralisation of power under Salazar's rule. Although the investigation covers only the period from April 1933 to May 1939, the dictator's diary facilitated a new look into the informal structures of power in Portugal during the first years of the New State. ${ }^{2}$

The article begins by providing an overview of the existing studies on the general features of the New State, and its relevance for understanding political centralisation and the role of the council of ministers after 1933. Based on the former, it focuses on the formal constitutional rules regulating the relationship between the prime minister and his cabinet, combining it with other contemporary sources. The core of the article then focuses on the actual practice of decision-making, using Salazar's personal notes as the major source for understanding collective and individual meetings with his ministers and inner-circle, including the frequency, political context and the political agenda of these meetings. The conclusions corroborate former interpretations, while also suggesting important nuances, which are of significant relevance for understanding the personalisation of power during the first years of Salazar as Portugal's de facto dictator.

\section{What do we know about political-decision making in Portugal under Salazar?}

Most of the existing research on political decision-making under dictatorial regimes focuses on the person of the dictator and the type of leadership expressed through discourses and practices. However, less effort has been made to understanding different levels of political centralisation and power distribution by focusing on other political institutions created by, or for, these regimes. With respect to Salazarism this is even more striking: the first generic studies appeared in the late 1960s and 1970s, and focused on the nature of the regime while representing some of the first attempts to compare Salazarism with other 'fascist regimes' (Lucena 1976; Schmitter 1975; Cabral 1976; Cruz 1988). As a result, competing interpretations emerged, indicating that either Portugal was governed by some sort of 'fascism without a movement' (Lucena 1976) or that 'not all authoritarianisms were fascist' (Cruz 1988; see Pinto 1995). Linz's seminal typology (1975) would later influence some of the more political and comparative interpretations of the New State, irreversibly classifying the regime as 'authoritarian' given certain of its features, such as its 'limited pluralism' (Pinto 1995). However, Linz's typology did not establish a direct link between regime type and the extent of the centralisation of decision-making. Although scholars agreed from the beginning that Salazarism could not be characterised as totalitarian, considerable work had yet to be done in order to understand the extent of power allocation by the 20th-century dictators, including Salazar. 
From the 1970s on, no more than occasional references to the level of political centralisation in Portugal can be found. One of the earliest references to the council of ministers provides a brief account of its role, based on a few statements by Salazar and his ministers (Cruz 1988). Cruz classified the council of ministers as a system of vertical accountability based on a type of dictatorial 'rule of law'. 'Salazar listened to his ministers and collected the greatest amount of information possible about the topic of discussion ... but he kept the final decision-making responsibility to himself' (Cruz 1988: 104). In a similar vein, one of the most recent contributions on the ministerial elites of the New State also concluded that:

the dictator effectively eliminated the council of ministers, which was soon replaced by meetings with individual ministers. Cabinet meetings had become purely symbolic by the mid-1930s, only taking place when there were foreign and domestic policy problems deserving to be shared with the nation, or when there were important cabinet re-shuffles.

(Almeida, Pinto and Bermeo 2003)
World War, which altered the frequency of council of minister meetings. As for individual meetings, the reader should bear in mind the analysis of 1933 is based on the months April-July.

As we shall see, this was not always the case.

It appears the prevailing notion about Salazar's governing style has not changed much over time.

While it would certainly be an exaggeration to claim Salazar created authoritarian rule in Portugal tout seul et de toutes pieces, the evidence suggests he played a very personal and imperious role in both the direction of policy after 1928 and in the backing of elites after 1932.

(Schmitter 1975: 52)

As research continues, we hope new studies on other instances of Salazarist decision-making will provide new insights and a more holistic interpretation of the New State's decision-making process. Our contribution will show how, overall, the majority of authors mentioned above were able to grasp the general idea about the role of the council of ministers and the distribution of powers under Salazar, although important nuances need to be clarified. The first step is to inquire whether rules are consistent with discourse and practice.

\section{The council of ministers: between formal rules, discourse and practice}

Salazar became head of government in July 1932, yet his convictions about the inefficiency of the council of ministers would only become practice in 1933, shortly before the new constitution had been enacted. In fact, during 1932, the press still referred to 'ordinary' meetings of the council of ministers - held every Friday - and 'extraordinary' meetings that were held under special circumstances (Diário de Notícias, January and September 1932). Hence, the established routine that characterised the military dictatorship since 1926 would continue for a few months after Salazar's appointment, until the council of ministers was transformed into an 'extraordinary' meeting of the whole cabinet. 
3. The president of the republic presided over the council of ministers under the following circumstances: to address the national assembly (article 81, section 2), name the date of a general or supplementary election (article 81 , section 3 ); bestow constituent authority in specific matters to the national assembly (article 81, section 4 , in the terms of article 134); convoke extraordinary meetings of the national assembly or to adjourn it (article 81, section 5); to dissolve the national assembly (article 81 , sect. 6); or to pardon or commute sentences (article 81, section 8).
Change came initially through discourse. If we consider Salazar's earlier statements, we can venture that his centralising tendency probably did not come as a surprise to the contemporary political elite. His 'propagandistic' interviews with António Ferro constitute some of the earliest evidence of his convictions about political decision-making. In an interview in early December 1932, Salazar began by exposing his anti-parliamentary views:

Even while acknowledging its necessity, parliament scares me so much that I am afraid of what will come out of it. Clearly there are always three months during which there can be good suggestions; but there are usually many speeches, many words. As a small parliament - which, as in the present case is useful and productive, the council of ministers is sufficient for me.

(Ferro 2003: 95)

Then, with the enactment of the constitution, Salazar transformed his convictions into formal rules, namely through what was not said about the council of ministers. According to previous interpretations, the constitution established a 'presidential' regime centred on the prime minister: Salazar (Cruz 1988). The council of ministers became nothing more than a meeting of 'ministers ... presided over by either the president of the council or the president of the republic' (Caetano 1963: 539). The only constitutional role attributed to the council of ministers was to nominate colonial governors, which may be interpreted as an expression of political centralisation, since the task of appointing colonial governors should, in principle, belong to the minister for the colonies (Constitution of the Portuguese Republic 1933, article 108). In effect, there was no specific section in the constitution dedicated to the council of ministers, and therefore no reference was made to a regular assembly of the cabinet. This aspect is noteworthy because it represented a formal and institutionalised break with the practices of the military dictatorship.

Our hypothesis is that by establishing little more than the president's conditions for presiding over the council of ministers, Salazar's concern was not only with constitutionally defining his relations with the cabinet, but also with the president of the republic, Óscar Carmona. In fact, the constitution states that the council of ministers should meet whenever the prime minister or the president judged it to be necessary (Constitution of the Portuguese Republic 1933, article 110). However, the president's 'need' was also constitutionally predetermined. ${ }^{3}$ It can be said that by constitutionally enforcing cabinet meetings to deal with such issues, Salazar guaranteed these decisions remained under his control. In addition to formal consultations with the council of state (in the case of the attribution of constituent powers, extraordinary meetings, postponements and dissolutions), the president was obliged to call a meeting of the council of ministers in all cases of conflict with the assembly. However, these meetings were not entirely autonomous and nor were they limited to liaison with the prime minister: they involved the entire cabinet. Resolution of institutional crises with the assembly was achieved through the implicit cooperation between the president and government.

All this contributed to the prime minister obtaining pre-eminence: it was the head of the executive branch, and not the government or the 
ministers, who answered to the president. Ministerial responsibility was exercised jointly with the prime minister, who coordinated and directed their activities. The appointment and replacement of ministers and undersecretaries was made by the president, but only on the advice of the prime minister, whose signature was required on all decrees. These facts indicate the tendency 'to transform the presidency into the nucleus of administrative services and bodies that, by their nature or through practical convenience, must be common to the entire government or be separated from the existing ministers' (Caetano 2005: 278), or a kind of secretariat or research office:

[W]ithin the presidency of the council is assembled a set of important administrative services of information, study, research and knowledge that makes of them a true ministry, in which the common questions of government and the general problems of policy are dealt: the prime minister may delegate to his ministerial assistants some of his management and coordinating authority as head of the presidency of the council.

(Caetano 1963: 531)

Salazar's way of reducing the council of minister's decision-making role was by ensuring it did not have to approve decree-laws, even when they had been signed by every minister (Decree-law 22470, 11 April 1933). Thus,

when the constitution says this or that matter is the responsibility of the government, it does not mean it needs to be exercised jointly by the prime minister and his ministers: it means each minister, exercising the administrative duties of the department under his control, possesses the authority constitutionally conferred on the government.

(Caetano 1963: 538)

It is interesting to note that this depiction of the council of ministers was elaborated by Marcelo Caetano; president of the executive commission of the single party, the National Union (UN - União Nacional), in 1947: head of the corporatist chamber from 1949-55, colonial minister from 1944-7 and Salazar's successor from 1968 until the regime's overthrow on 25 April 1974.

Caetano, who was one of the regime's major ideologists, and had the personal experience of relating with Salazar as a minister in the 1940s, made some recommendations when analysing the role of the council of ministers, which supports the idea that the centralisation of power, more than ideology, was a personal conviction of Salazar: 'whenever the material involves a declaration of law, it is advisable that it be approved by the council of ministers, notwithstanding the fact it will later be examined by the competent legislative services of the presidency of the council and, preferably, reviewed by the corporate chamber'. That was not how Salazar worked, as Caetano himself would find out: 'as the signature of each minister was pledged individually' (Caetano 1963: 533-4). Only for a short period during the 1950 s did he respond to Caetano's request by creating bi-monthly meetings; however, these did not endure. 
Salazar's beliefs would only become stronger over time, namely after the end of the Second World War and the reshaping of the European political framework. In effect, following a ministerial reshuffle in August 1940, Salazar highlighted the role of strong leadership. He believed the "poor yield of [democratic] systems' was due mainly to what he called a waste of time. It is clear that, rather than as a government, he viewed his ministers as a group of experts with whom the leader should consult. 'Except for those meetings that are held to discuss either essential policy matters or to provide general guidance, systematic work in cabinet must be of poor value and low quality - in addition to the time the ministers lose.' Thus, compared to other political systems and regimes, the governance of the New State possessed clear advantages (Salazar 1943: 271-2).

The best method is without doubt that which we have used for years: that of the head of government working with the minister or ministers whose portfolios are directly affected by the problem, or of small committees that are constituted and with legal attributes to deal with sets of problems, as in the cases of the corporatist council and the council of ministers for external commerce.

(Salazar 1943: 272)

The combination of formal rules and discourse leads us to conclude there were three main types of meetings between Salazar, his ministers and the inner-circle: a) exceptional meetings of the council of ministers that were held only on specific occasions; b) one-to-one meetings between Salazar and a minister to solve problems directly associated with a specific portfolio and policy area; and c) 'specialist councils'. We will explore the main characteristics of each separately.

\section{Meetings of the council of ministers}

During his early years as prime minister (1933-9), Salazar met his council of ministers on 94 days, representing an average of 15 meetings per year. However, the average is an insufficient instrument for this analysis, as the concentration of meetings during specific periods of time is one of the interesting features. In other words, the non-systematic gathering of the cabinet is one of the most important points, and one that deserves further elaboration. Secondly, what makes the analysis interesting is to understand, on the one hand, how these meetings were distributed over time, and what Salazar in practice considered 'essential policy matters and general guidance' during the regime's early years.

Starting with the timeline distribution, what becomes clear is the lack of regularity. In 1935 there were three meetings every two months, while during the years until 1938 the cabinet met once each month, after which it averaged three meetings every four months. Figure 1 illustrates this tendency.

With respect to the topics on the agenda, our observations show that the main subjects discussed at the meetings ranged from current affairs ( 52 per cent) to debate over political reform (13 per cent), social and political domestic crises ( 24 per cent) and international politics (11 per cent). If we put together the three 'exceptional' topics (political reform, 


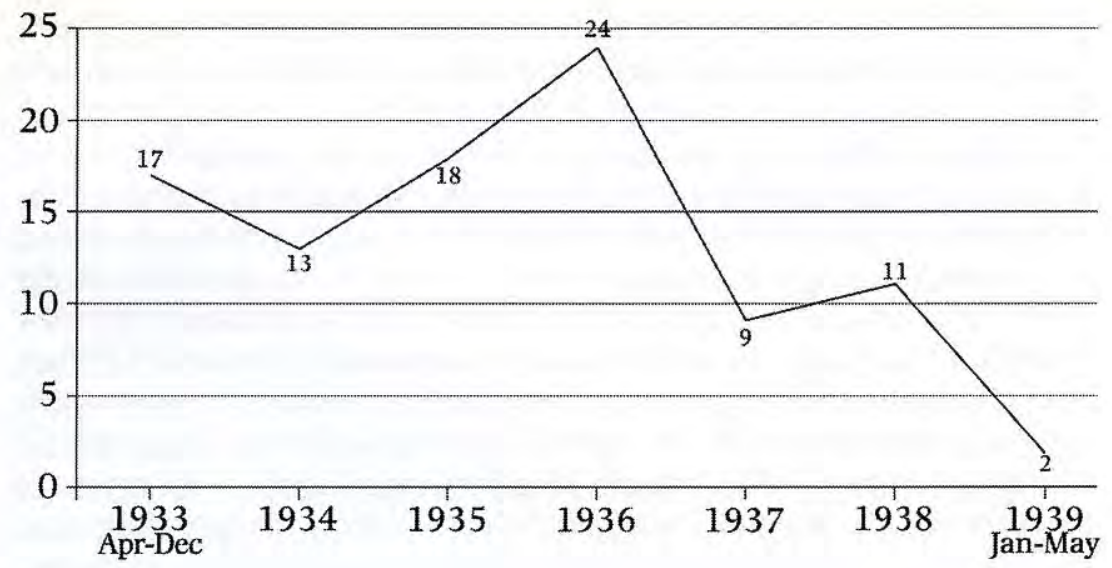

Figure 1.

social and political crises and international politics - the latter including only the topics relating to the political context and conflicts in inter-war Europe), the interpretation becomes slightly different. On this first attempt to evaluate council of ministers' agenda during this period, we can tentatively conclude that only 52 per cent of the meetings were dedicated to current affairs, i.e., approximately half of the times Salazar decided to gather the whole cabinet, something 'exceptional' was on the table. This suggests Salazar met his cabinet not so much to handle 'essential policy matters', but on urgent matters of 'general guidance'. What we still do not know is whether there was any real deliberation, or if the meetings were merely to provide a formal endorsement of Salazar's decisions.

The average of monthly meetings in 1933, after Salazar was appointed head of government for the second time, is the highest of this initial period of the New State. From the promulgation of the constitution until the end of 1933, Salazar met his council of ministers on average twice a month. This was probably in part due to a 'legacy' of the military dictatorship (his predecessor had a regular Friday appointment with the entire cabinet), but primarily it expresses Salazar's decision to get the approval of the whole cabinet on the several stages of the regime's institutionalisation. On the table were the corporatist organisation of the state, the administrative code and the electoral rules. Current issues relating to the colonies and the agricultural cereal regime were also discussed.

\begin{tabular}{llcc}
\hline Current affairs* & $\begin{array}{l}\text { Political reform and } \\
\text { institutionalisation }\end{array}$ & $\begin{array}{c}\text { Domestic social } \\
\text { and political crises }\end{array}$ & $\begin{array}{c}\text { International } \\
\text { politics }\end{array}$ \\
\hline
\end{tabular}

52

13

24

11

* This category includes foreign affairs as both a governmental and policy area. It is distinct from what is classified as 'international politics', which includes contextual concerns typical of the inter-war period.

Note: Categories were created according to the information provided by Salazar in his diary. When the information was insufficient, other sources were used.

Table 1: Topics discussed at the council of ministers by category (\%). 
In 1934 the corporatist organisation was still being debated, but what is most striking about the meetings of the council of ministers in this year which were significantly less frequent than in previous or succeeding years was Salazar's decision to involve his cabinet in the management of all domestic social and political crises. Why would a strong dictator, a non-charismatic leader, a face-to-face reduced-inner-circle governor, decide to gather his ministers to make decisions on what to do with the opposition to the regime? Beginning with the major trade union strike against the corporatist organisation and in support of free labour movements (18 January 1934) and ending with the threat represented by Rolão Preto's blue shirt movement, Salazar brought them all to the council of ministers. After the latter episode, the cabinet appeared to be some sort of instrument to legitimise the powers of the dictator. One day after Preto confronted Salazar by directly addressing him in a protest letter (following which he and his deputy, Alberto Monsaraz, were exiled to Spain), the cabinet met to show its support for Salazar.

In 1935 , the opposition to the regime, which included the working class movement, the Integralists and the Freemasons, was again a major concern for Salazar, whose diary indicates actual measures were discussed with his ministers, including the idea of purging the public administration and forcing the most prominent leaders into exile.

The international situation became of pressing concern to Salazar in 1936. One of the most interesting observations is perhaps the change of topics from 1936 to 1937 . In May 1936 Salazar dismissed the minister of war and took over the portfolio himself. A few months later, in November, Salazar also took over the ministry of foreign affairs. This seems to have had an impact on the already reduced role of the council of ministers. By 1937, despite the outcome of the Spanish civil war remaining uncertain and the remilitarisation of the Rhineland, concerns over existing and potential conflicts were no longer of central importance to the council of ministers. This is even more striking when we note that on 19 February 1937, Salazar met some trusted colleagues - the minister of the interior, Mário Pais de Sousa, the minister of justice, Rodrigues Junior, and the secretary-general of the foreign ministry, Teixeira de Sampaio - to discuss (without the involvement of the council of ministers) the introduction of a regulation to prohibit Portuguese citizens from becoming involved in the civil war in Spain.

From 1938 until the end of the period being studied, international politics remained outside the political agenda, despite the ongoing nature of the civil war in Spain and the steady march of Europe to war. New matters relating to the regime's opposition were dealt with, as were several minor issues, such as ship transport for the colonies and the preparations for the 1940 world exhibition in Lisbon.

The analysis of the frequency of meetings and the council of ministers' agenda indicates both the unwillingness of Salazar to gather the whole cabinet on a regular basis, and his decision to deprive it of decision-making power: particularly in respect to current political affairs. As suggested by Salazar's own declarations, and in order to accurately examine the extent of his political centralisation, the question remains whether the Portuguese dictator formed smaller and restricted councils of ministers, or held individual meetings at which he discussed the matters of each portfolio in a more efficient and deliberate manner. 


\section{Meetings between the prime minister and his ministers}

The period April 1933-May 1939 provides elements for rethinking both the distribution of power during the regime's institutionalisation and the importance Salazar attributed to various ministerial portfolios. More precisely, we believe that the frequency with which Salazar met with his ministers individually partly explains both how much he sought to control the issues and the degree of autonomy granted to the minister. Following the analysis of individual meetings between Salazar and his ministers - once again based on his personal notes - our research shows it is possible to group the ministries as follows: (1) the most important: interior; (2) the intermediate: commerce and industry, public works and foreign affairs (until Salazar assumed personal control); (3) of little importance: agriculture, navy and colonies; and (4) of residual importance: justice, war and education. Table 2 illustrates this.

The most important portfolio was clearly that of the interior ministry, although only from 1936, when Mário Pais de Sousa took control of the office. Salazar reshuffled this ministry three times between 1933 and $1936,{ }^{4}$ and during those initial three years the frequency of meetings with each minister suggests that not every portfolio had the same importance. Salazar met with the first interior ministers just as much as he did with the ministers of justice, war and education. This first case shows that the difficulty in analysing the importance of portfolios vis-á-vis ministers is due to the fact that the frequency of meetings with ministers did not always reflect the extent of their ability to act autonomously or the extent of their involvement in the decision-making process. Although it is undeniable that the interior ministry was a highly important portfolio in the New State, the individual who held the position was also, in this case, important. ${ }^{5}$

Commerce and industry was the next most important portfolio in terms of the regularity of its meetings with Salazar. ${ }^{6}$ Indeed, until the outbreak of the Spanish civil war in 1936, this was apparently the most important ministry in terms of the contact time the minister had with Salazar. However, it is curious to note the minister who held this office until 1936 was not only an important figure in the initial construction of the corporatist organisation (which was a major feature of Salazar's regime), he was also the person to whom Salazar turned 'for counsel over matters related to Spain and for the establishment of links with Franco, using his personal connections with Gil Robles' (Alexandre 2000: 207).

Next in the order of importance came the ministry of public works and communications. Except for the period 1936-8, this ministry was headed by Duarte Pacheco, a man who was close to Salazar. Despite the intensity of the legislative activity of the latter, the prime minister clearly preferred the epistolary exchange instead of face-to-face meetings that he would keep with the former. In 1938, the number of meetings with the minister of public works increased to such an extent that they supplanted those with the minister for commerce and industry.

Curiously, the ministry of foreign affairs - which Salazar took control of in 1936 - was treated with less importance during the first three years. The personal profiles of the holders of these offices perhaps explain this difference (Caeiro da Mata [1933-5] and Armindo Monteiro [1935-6]). It seems Salazar acted as the holder of this portfolio from the outset, although
4. The first was Albino dos Reis (1933), who was appointed during the military dictatorship, the second was Gomes Pereira (1933-4) and the third was Linhares de Lima (1934-6).

5. It would seem Caetano's contention that there was a group of portfolios with easier personal access to the head of government, while there were others that were restricted to brief meetings, telephone conversations and written correspondence, does not seem to be sustainable (Caetano 2000: 313-9).

6. During the period being studied, this ministry was headed by Sebastião Garcia Ramirez (1933-6), Teotónio Pereira (1936-7) and Costa Leite (1937-40). 


\begin{tabular}{|c|c|c|c|c|c|c|c|c|c|}
\hline & Total & 1933 & 1934 & 1935 & 1936 & 1937 & 1938 & 1939 & Portfolio \\
\hline Albino dos Reis & 14 & 2 & 6 & 3 & 1 & 2 & 0 & 0 & Interior \\
\hline Gomes Pereira & 25 & 2 & 23 & 0 & 0 & 0 & 0 & 0 & Interior \\
\hline Linhares de Lima & 19 & 1 & 5 & 12 & 1 & 0 & 0 & 0 & Interior \\
\hline Pais de Sousa & 828 & 0 & 26 & 40 & 184 & 252 & 264 & 62 & Interior \\
\hline Manuel Rodrigues & 76 & 4 & 21 & 12 & 9 & 20 & 10 & 0 & Justice \\
\hline $\begin{array}{l}\text { Luís Alberto de } \\
\text { Oliveira }\end{array}$ & 22 & 9 & 8 & 0 & 0 & 2 & 3 & 0 & War \\
\hline Passos e Sousa & 30 & 0 & 7 & 13 & 10 & 0 & 0 & 0 & War \\
\hline $\begin{array}{l}\text { Mesquita } \\
\text { Guimarães }\end{array}$ & 71 & 7 & 23 & 25 & 5 & 1 & 6 & 4 & Navy \\
\hline $\begin{array}{l}\text { Ortins de } \\
\text { Bettencourt }\end{array}$ & 79 & & & & 23 & 27 & 25 & 4 & Navy \\
\hline Caeiro da Mata & 69 & 11 & 33 & 16 & 7 & 1 & 0 & 1 & Foreign \\
\hline $\begin{array}{l}\text { Mesquita } \\
\text { Guimarães }\end{array}$ & 4 & & & 4 & & & & & Foreign \\
\hline $\begin{array}{l}\text { Armindo } \\
\text { Monteiro }\end{array}$ & 131 & 10 & 22 & 46 & 50 & 0 & 3 & 0 & $\begin{array}{l}\text { Foreign/ } \\
\text { Colonies }\end{array}$ \\
\hline Duarte Pacheco & 285 & 27 & 50 & 47 & 6 & 21 & 105 & 29 & Public works \\
\hline $\begin{array}{l}\text { Joaquim Silva } \\
\text { Abranches }\end{array}$ & 23 & 0 & 0 & 0 & 16 & 0 & 7 & 0 & Public works \\
\hline Bossa & 19 & 0 & 0 & 13 & 4 & 1 & 0 & 1 & Colonies \\
\hline $\begin{array}{l}\text { Francisco (Vieira) } \\
\text { Machado }\end{array}$ & 76 & 0 & 2 & 1 & 14 & 21 & 32 & 6 & Colonies \\
\hline Cordeiro Ramos & 2 & 2 & 0 & 0 & 0 & 0 & 0 & 0 & Education \\
\hline Sousa Pinto & 30 & 5 & 14 & 2 & 3 & 2 & 3 & 1 & Education \\
\hline Manuel Rodrigues & & & 12 & & & & & & Education \\
\hline Eusébio Tamagnini & 26 & 0 & 5 & 19 & 1 & 0 & 1 & 0 & Education \\
\hline Carneiro Pacheco & 56 & 0 & 15 & 15 & 14 & 4 & 6 & 2 & Education \\
\hline Garcia Ramirez & 258 & 22 & 63 & 69 & 38 & 49 & 12 & 5 & $\begin{array}{l}\text { Commerce } \\
\text { and industry }\end{array}$ \\
\hline Teotónio Pereira & 206 & 26 & 52 & 19 & 47 & 42 & 19 & 1 & $\begin{array}{l}\text { Commerce } \\
\text { and industry }\end{array}$ \\
\hline Costa Leite & 183 & 0 & 9 & 34 & 30 & 31 & 67 & 12 & $\begin{array}{l}\text { Commerce } \\
\text { and industry }\end{array}$ \\
\hline $\begin{array}{l}\text { Queimado de } \\
\text { Sousa }\end{array}$ & 14 & 2 & 10 & 2 & 0 & 0 & 0 & 0 & Agriculture \\
\hline Neves Duque & 156 & 0 & 4 & 37 & 39 & 22 & 40 & 14 & Agriculture \\
\hline
\end{tabular}

Prior to holding office

As under-secretary

As minister

After holding office

Interim for more than one month

Table 2: Meetings with ministers before, during and after holding office. 
he did not officially assume responsibility until November 1936. Given that, it is clear foreign affairs was an important portfolio.

The departments of justice, agriculture, navy and colonies were rooted at a regularly low level throughout this period. Once again, this analysis considers whether the lack of meetings between Salazar and other senior government officials may have a linear and immediate significance: the prime minister's devaluation of certain portfolios. In this case, it is important to review the activities of the minister of justice, Manuel Rodrígues Junior, who was the longest serving minister of this period (1932-40). As far as can be ascertained, Rodrígues Junior had substantial decision-making powers. It was he who proceeded with important legal reforms such as the reorganisation of the Superior Council of the Justiciary (CSJ - Conselho Superior Judiciário) in 1933, who elaborated the electoral law in 1934 and promulgated the decree outlining sanctions for serving with an enemy in 1935. The few meetings he had with Salazar were concerned mainly with the domestic political situation.

In this way it is possible to conclude that a minister's profile was the determining factor in relation to the number of meetings they were able to have with the prime minister. This can be supported through an analysis of the number of meetings Salazar held with those who had previously exercised ministerial functions and those who were yet to rise to ministerial office. Those who were closest to Salazar were those who met him more often. Garcia Ramirez, Duarte Pacheco and Teotónio Pereira continued to be heard after they had left office. Another main criterion that facilitated face-to-face meetings with Salazar was technical competence. Falling into this category were the minister of public works and the minister of commerce, with both holding the office longer than any other. In both cases, it is worth highlighting the fact that Salazar did not end the face-to-face meetings and conversations after they were replaced. With the former, all of the meetings were on the matter of public works, and only rarely were they related to Lisbon municipal council (of which Pacheco was mayor 1936-8). With the latter, meetings between the two were frequent even before 1932 .

The same can also be said of Pedro Teotónio Pereira who, as an undersecretary of state, had more meetings with Salazar than the minister of justice, Manuel Rodrigues. Thus, the claim made by Teotónio Pereira as he recalled his time as under-secretary of state for corporations, that 'the prime minister adopted a system of working individually with each minister that meant he had very little free time in which to organise his weekly schedule,' is unlikely to be true (Pereira 1972: 109).

Finally, we note Salazar held more meetings with the director-general of public accounts, António José Malheiro, than he did with the under-secretary of state for finances. The same was true of the secretary-general of the ministry of foreign affairs, who had almost as many meetings with the prime minister as the portfolio's ministers. What we do not know is if these meetings took place with the minister's consent or approval.

As for the 'mini-council of ministers', it is true Salazar met with two or three ministers at a time to discuss matters that could interest several ministries. Some of the most important examples are: meetings with the ministers of foreign affairs and of commerce (together with the general secretary of foreign affairs) to discuss commercial agreements with France 
7. There are occasions during which Salazar travels to his hometown and does not take his usual notes. According to other sources, meetings with ministers and his inner-circle did take place when Salazar was in Santa Comba Dão (Matos 2003). However, we believe these lacunae are not sufficient to alter our general conclusions.

8. According to the Dicionário de história do Estado Novo, Sampaio 'was the right hand of all foreign ministers, who rarely made a decision without first seeking his opinion, and he always accompanied them when they met with the head of government'. 'From 1935, when Salazar began to pay more attention to the international situation, it was with the hard-working Sampaio that he met to establish the broad lines of the regime's foreign policy' (Rosas and Brito 1996: 876). and the Netherlands (1934) and with Spain (1936); meetings with the ministers of agriculture and of commerce, both in 1934 and 1935, to discuss specific decree-laws related to these ministries; meetings with the ministers of justice and of the interior (often with the head of the political police) to deal with the political crises and measures to deal with political prisoners.

This overview of Salazar's meetings with ministers demonstrates that in many cases he preferred individual and small-group meetings to "wasting time' by gathering the whole cabinet. However, we do not yet possess enough information on the nature of the deliberations that took place in these meetings. In this sense, it is important to note that conclusions about Salazar's meetings with men he trusted - be they ministers, holders of other political offices, or mere friends - are limited to often insufficient sources.

Below we will provide an approximate idea of the formal and informal structures of power without suggesting definite conclusions. This final part is dedicated to other trusted men who did not hold ministerial rank, but of whom it is important to be aware if one seeks to understand decision-making in Salazar's state.

\section{Other political officials and their friendships with Salazar ${ }^{7}$}

In terms of positions below ministerial rank, the most noteworthy individual around Salazar was Teixeira de Sampaio (secretary-general of the ministry of foreign affairs). ${ }^{8}$ Although they did not meet often (Sampaio was in London, where he was ambassador, for much of the time), they remained in contact by telephone and telegram.

During this period, the rank of under-secretary of state was immediately below that of minister. Our research indicates that in the majority of cases neither these offices, nor the individuals who held them (e.g., Leovigildo Franco de Sousa, Águedo de Oliveira, Vaz Serra and Espregueira Mendes) were particularly close to Salazar or important for decision-making. The three exceptions were those of corporations, occupied by Teotónio Pereira (1933-6), finances, and war - two of Salazar's own portfolios. Costa Leite occupied the former from 1934-7, while Santos Costa served in the latter between 1936 and 1944. It is worth noting that the individual often made a difference.

Unsurprisingly, neither the national assembly nor the corporatist chamber seems to have been important to Salazar. This assertion is based on the number of times he met their respective presidents. As prime minister, he met national assembly president, José Alberto dos Reis, only 31 times between April 1933 and May 1939, and met corporatist chamber president Eduardo Marques ten times over a similar period.

However, António Ferro, director of the National Propaganda Secretariat (SPN - Secretariado de Propaganda Nacional), was constantly at the prime minister's side. It is worth noting that there was no ministry of propaganda, and nor was there any under-secretariat.

The number of times Salazar held meetings with the leaders of the UN and the Portuguese Youth (MP - Mocidade Portuguesa) is not mentioned. The only exception to this was Costa Leite who, as well as being president of the Portuguese Legion's (LP - Legião Portuguesa) central committee from 1936-44, was also under-secretary of state and then minister of finance.

Table 3 highlights one aspect of our analysis that is difficult to measure: the exercise of informal power by those who surrounded Salazar. In this 


\begin{tabular}{|c|c|c|c|c|c|c|c|c|c|}
\hline & Total & 1933 & 1934 & 1935 & 1936 & 1937 & 1938 & 1939 & Position \\
\hline Aguedo de Oliveira & 1 & 1 & 0 & 0 & 0 & 0 & 0 & 0 & Finances under-secretary to 23 Oct 1934 \\
\hline Vaz Serra & 2 & 0 & 0 & 0 & 0 & 0 & 2 & 0 & Finances under-secretary from 13 Dec 1935 \\
\hline Espregueira Mendes & 0 & 0 & 0 & 0 & 0 & 0 & 0 & 0 & $\begin{array}{l}\text { Public works under-secretary from } 7 \text { Jun } \\
\text { 1938-6 Sep 1944; Communications under-secretary from } 6 \text { Jun } \\
\text { 1944-4 Feb } 1947\end{array}$ \\
\hline Santos Costa & 396 & 0 & 0 & 5 & 79 & 154 & 128 & 30 & War under-secretary from 12 May 1936 \\
\hline Teixeira de Sampaio & 803 & 9 & 22 & 28 & 116 & 262 & 249 & 117 & Foreign affairs secretary general. \\
\hline Fezas Vital & 77 & 2 & 13 & 20 & 22 & 17 & 1 & 2 & Jurist and university professor \\
\hline António Ferro & 131 & 7 & 18 & 23 & 22 & 14 & 35 & 12 & National Propaganda Bureau (SPN) director \\
\hline José Nosolini & 73 & 3 & 12 & 15 & 11 & 13 & 16 & 3 & UN leader, governor of Funchal \\
\hline Nobre Guedes & 19 & 0 & 9 & 2 & 4 & 2 & 2 & 0 & UN and MP leader \\
\hline Óscar Carmona & 66 & 4 & 14 & 8 & 15 & 5 & 17 & 3 & President of the republic \\
\hline José Alberto dos Reis & 31 & 2 & 1 & 11 & 9 & 5 & 3 & 0 & President of the national assembly from 1935 \\
\hline Eduardo Marques & 10 & 0 & 0 & 4 & 2 & 3 & 1 & 0 & President of the corporatist chamber from 1935 \\
\hline $\begin{array}{l}\text { António José } \\
\text { Malheiro }\end{array}$ & 338 & 32 & 69 & 119 & 34 & 55 & 29 & 0 & Treasury director general \\
\hline Namorado de Aguiar & 0 & 0 & 0 & 0 & 0 & 0 & 0 & 0 & Commander-general of the LP from 1936 \\
\hline Casimiro Teles & 0 & 0 & 0 & 0 & 0 & 0 & 0 & 0 & Commander-general of the LP from 1937 \\
\hline
\end{tabular}

Prior to holding office

As undersecretary

While in office

Table 3: Meetings with other political office holders. 
9. Salazar was also close to other people, although he saw them a great deal less often: Serras e Silva (27 times); Sebastião Garcia Ramirez (18); Teixeira de Sampaio (18); José Nosolini (his political advisor who held several political and administrative offices); Duarte Pacheco (11); Nunes Mexia (eight); Teotónio Pereira (seven); Mário de Figueiredo (seven); Cardinal Manuel Cerejeira (six) and; Diniz da Fonseca (five). We can also add the names of Carneiro de Mesquita and Josué Trocado, whom Salazar met frequently to attend Sunday mass. group, we include people who did not hold any particular political office, but who often spent informal time with Salazar, in many cases gossiping about politics. The most noteworthy of these were Bissaia Barreto, the Lacerda family, Mário Pais de Sousa and José António Marques. The common factor among them is their background: they were all from Coimbra, the city in which Salazar graduated and the university at which he taught.

Of these, the name of Bissaia Barreto is significant. Barreto was a deputy in the constituent republican assembly of 1911 when he represented the Evolutionist Party. He was a freemason and a member of the Coimbra Carbonaria, and joined the UN when it was formed in 1930 , becoming a member of its central commission on 5 July 1932. He was also appointed procurator of the corporatist chamber in 1961. His republican origins led many to believe he represented 'the New State's main republican guarantee'. Salazar lunched with Barreto no fewer than 186 times during the period being studied, and was recorded as being in the prime minister's company no fewer than 195 times.

We should also note the case of Jerónimo Lacerda, who graduated from the University of Coimbra where he became a lecturer in the medicine faculty. He founded the Caramulo sanatorium and headed the UN's district commission in Tondela. In total, members of the Lacerda family met Salazar informally 89 times between April 1933 and May 1939.

Salazar's sister's brother-in-law, Mário Pais de Sousa, had 76 informal meetings with the prime minister. Pais de Sousa was a law graduate and a member of the Christian Democracy Academic Centre (CADC - Centro Académico de Democracia Cristã) that emerged from the republican Liberal Republican Union (ULR - União Liberal Republicana). He had supported the 28 May coup in 1926, and served as interior minister during the consequent military dictatorship. He went on to become a leader of the UN and a deputy in the national assembly. Under Salazar he served as interior minister from 18 January 1936 to 6 September 1944.

Finally, there was José António Marques. Marques, who was from Santa Comba Dão, had abandoned the priesthood before graduating in law from the University of Coimbra - where he was one of Salazar's contemporaries in 1911. He had served as mayor of Santa Comba Dão, under-director at the office of the Supreme Court of Justice (STJ - Supremo Tribunal de Justiça) and as a deputy in the national assembly (Brochado 1987: 138-9). Salazar met Marques informally 38 times; however, if we are to calculate the number of times these men were together, we reach a figure of $293 .^{9}$

These statistics place in doubt the idea that dominant interests sought to influence Salazar and his political decisions informally. It is important to highlight the names that one would expect to appear frequently, based on existing literature and research about Salazar: Cardinal Cerejeira, Diniz da Fonseca and Mário de Figueiredo who, according to his diary, had very few meetings with Salazar. This is even more surprising if we bear in mind they were all personal friends of Salazar from the CADC.

\section{Conclusions}

The first conclusion leads to the idea that if 'Salazar created the single party ... from above, ensuring it remained weak and elitist from its very foundations in 1930' (Pinto 2002: 413), the same happened with his 
ministers. The records of Salazar's meetings with the ministerial elite support the notion he was a 'strong dictator', not because he was a charismatic leader, but due to his 'extensive centralisation of decision-making' (Pinto 2002: 413). However, although the single-party and the cabinet were, in practice, very weak institutions in terms of decision-making power, Salazar did have his personal counsellors - some of whom were appointed ministers at a certain moment - which created a certain confusion between public office and personal trust that is not always easy to disentangle.

However, it is important to note that these conclusions do not cover the entire duration of Salazarism. Franco Nogueira, who as well as being Salazar's official biographer was minister of foreign affairs 1961-9, noted the existence of different phases during which cabinet meetings were held with some regularity: in 1951 'his conviction that the work of the cabinet in plenary was of limited use took root' and 'he returned to his habit of working with each minister individually' (Nogueira 1977: 208, 212). During the initial period of Salazar's rule the analysis shows that, with respect to the council of ministers, there was no government routine and neither was there any regularity of meetings. There was nothing similar to Mussolini's grand council, which met on the 12th day of each month (see Adinolfi's article in this journal). It would appear Salazar's cabinet was little more than a crisis management committee in which meetings were determined by the situation.

As for the ministers, everything indicates that - with the exception of the interior ministry - meetings had more to do with general policy than with matters for which the ministries were responsible. Thus, in portfolios such as the ministry of justice, meetings with the ministers were mainly consultative. The technical competence of the ministers was more highly valued than their political charges: examples of this include those of Malheiro, Fezas Vital, Santos Costa, Teixeira de Sampaio, Rafael Duque and Duarte Pacheco. Political experience was also valued - and not necessarily at the head of any particular ministry. Examples include Garcia Ramirez, Pais de Sousa and Teotónio Pereira. As for the informal level, those who were close to Salazar were not generally politicians, and the political duties they performed were more that of interlocutors, since Salazar favoured technical competence and political and personal trust.

Although conclusions are not particularly striking, they do contribute to enhancing the accuracy of what is known of Salazar's style of governing. While Pinto sustains the council of ministers gathered 'only when there were major external or domestic policy issues that required demonstrations of a united front for the nation' (Pinto 2002: 433), this analysis of Salazar's personal notes shows the council of ministers was called to pronounce on issues that required swift responses, and not necessarily on policy issues. Examples include the trade union opposition of 1934, the outbreak of the civil war in Spain in 1936, the bomb attacks of 1937 and the alleged conspiracies against the regime in 1938.

What then can be said of the Portuguese case in the light of current knowledge of the allocation of political power in 20th-century dictatorships? Franco's Spain seems to be one European dictatorship in which the council of ministers played the predominant decision-making role. 
According to Jerez Mir, being a trusted minister of Franco meant empowerment and a high degree of autonomy (except in such portfolios as internal security and external affairs) (see Jerez Mir's article in this journal). Our research indicates Portugal was different.

The lack of a pattern of decision-making allocation in the fascist-era dictatorships transforms the generalisation of single cases into a bold task. Moreover, different methodological approaches seem to highlight the existence of competing interpretations between centralisation, empowerment and decision-making: namely, in the actual case of dictatorial regimes. Some authors have concluded that on some occasions, ministerial recruitment may be a strategy to keep an individual under control instead of empowering them, or to give representation to informal 'political families'. However, if the New State was more similar to Francoism than it was to Fascist Italy or Nazi Germany (Pinto 1996), this is one of the dimensions in which this does not hold true. In fact, despite surrounding himself with competent ministers, Salazar refused to allow them anything but the smallest margin of autonomous decision-making.

\section{References}

Alexandre, P. M. (2000), 'Ramirez, Sebastião Garcia', in Barreto, A. and Mónica, M. F. (eds), Dicionário de história de Portugal, Oporto: Figueirinhas.

Almeida, P. T., Pinto, A. C. and Bermeo, N. (eds) (2003), Who governs Southern Europe? Regime change and ministerial recruitment, 1850-2000, London: Frank Cass.

AOS (Arquivo Oliveira Salazar), AOS/CO/PC-8F, part 1 (1932-1940), Arquivo Nacional Torre de Tombo, Lisbon.

Brochado, C. (1987), Memórias de Costa Brochado, Lisbon: Livraria Popular Francisco Franco.

Cabral, M. V. (1976), 'Sobre o fascismo e o seu advento em Portugal: ensaio de interpretação a pretexto de alguns livros recente', Análise Social XII (48): 873-915.

Caetano, M. (1963), Manual de ciência política e direito constitucional, Lisbon: Coimbra.

—. (2000), Minhas memórias de Salazar, Lisbon: Verbo.

—. (2005), Manual de direito administrativo, vol. I, Coimbra: Almedina.

Constitution of the Portuguese Republic 1933.

Cruz, M. B. da (1988), O partido e o estado no Salazarismo, Lisboa: Presença.

Decree Law 22470, 11 April 1933.

Diário de Lisboa, 4 February 1935.

Diário de Notícias, January-September 1932.

Ferro, A. (1933), Salazar: O homem e a sua obra, Lisbon: Empresa Nacional de Publicidade.

—. (2003), Entrevistas de António Ferro a Salazar, Lisbon: Parceria A. M. Pereira.

Linz, J. (1975), 'Totalitarian and authoritarian regimes', in Greenstein, F. and Polsby, N. (eds), Handbook of political science, vol. 3, Reading, MA: AddisonWesley, pp. 175-411.

Lucena, M. (1976), A evolução do sistema corporativo português, vol. I, O Salazarismo, Lisbon: Perspectivas e Realidades.

Matos, H. (2003), Salazar: A construção do mito, Lisbon: Temas e debates. 
Nogueira, F. (1977-85), Salazar, vols 1-6, Oporto/Coimbra: Civilização/Atlântida.

Pereira, P. T. (1972), Memórias: Postos em que servi e algumas recordações pessoais, vol. 1, Lisbon: Verbo.

Pinto, A. C. (2002), 'Elites, single-parties and political decision-making in fascistera dictatorships', Contemporary European History 11(3): 429-54.

Pinto, A. C. (1996), Salazar's dictatorship and European fascism: Problems of interpretation, Boulder, NY: Social Science Monographs.

Rosas, F. and Brito, J. M. B. de (1996), Dicionário de história do Estado Novo, Lisbon: Círculo de Leitores.

Salazar, A. O. (1943), 'Orgânica ministerial e trabalho do governo', Discursos e notas políticas: 1938-43, Coimbra: Coimbra Editora.

Schmitter, P. C. (1975), Corporatism and public policy in authoritarian Portugal, London and Beverly Hills, CA: Sage.

\section{Suggested citation}

Raimundo, F., Ferreira, N. E. and de Carvalho, R. A. (2009), 'Political decisionmaking in the Portuguese New State (1933-39): The dictator, the council of ministers and the inner-circle', Portuguese Journal of Social Science 8 (1): 85-101, doi: $10.1386 /$ pjss.8.1.85/1

\section{Contributor details}

Filipa Raimundo is currently a doctoral researcher in political science at the European University Institute, where she is developing a comparative study of post-transitional justice in four European democracies.

Contact: Filipa Raimundo, European University Institute, Department of Social and Political Sciences, Via dei Roccettini, 9, 50014 San Domenico dei Fiesole, Florence, Italy.

Tel: +351916225834

E-mail: filipa.raimundo@eui.eu

Nuno Estêvão Ferreira is a doctoral candidate at the Institute of Social Science, University of Lisbon, where he is concluding his thesis on the corporatist chamber of the Portuguese New State.

Contact: Nuno Estêvão Ferreira, Institute of Social Science, University of Lisbon, Av. Professor Aníbal Bettencourt, 9, 1600-189 Lisbon.

Tel: +351217804700

E-mail: nuno.ferreira@ics.ul.pt

Rita Almeida de Carvalho is a doctoral candidate at the New University of Lisbon's department of history, where she is concluding her thesis on the relations between Portugal and the Vatican during the 1940s.

Contact: Rita Almeida de Carvalho, Institute for Contemporary History, Universidade Nova de Lisboa, Av. de Berna, 26C, 1069-061 Lisbon.

Tel: +351 217908300

E-mail: rita.carvalho@ics.ul.pt 